\title{
Pengembangan Media Pembelajaran Interaktif Berbasis Android Untuk Pembelajaran Teknik Animasi 2 Dan 3 Dimensi Kelas XI Sekolah Menengah Kejuruan
}

\author{
Rizma Panca Patriani dan Indrati Kusumaningrum \\ Universitas Negeri Padang \\ E-mail : rizmapp@gmail.com dan inkoes_pdg@yahoo.co.id \\ Diterima: Februari 2020 ; Dipublikasikan Juli 2020
}

\begin{abstract}
ABSTRAK
Permasalahan yang ditemui dalam pembelajaran Teknik Animasi 2 dan 3 Dimensi yaitu beberapa KD lebih diarahkan pada tingkat pemahaman konsep sehingga diperlukan pemahaman kognitif siswa. Pada proses pembelajaran banyak siswa terkendala dalam memahami materi dari penjelasan guru melalui tayangan video ataupun slide power point sehingga guru harus mengulang kembali materi yang sebelumnya sudah disampaikan mengakibatkan pembelajaran kurang efektif. Kecendrungan siswa lebih menyenangi pembelajaran praktik ketimbang teori sehingga hasil belajar kognitif masih rendah. Penelitian ini bertujuan untuk mengatasi masalah tersebut dengan mengembangkan media pembelajaran interaktif berbasis android untuk pembelajaran Teknik Animasi 2 dan 2 Dimensi sehingga dapat meningkatkan hasil belajar siswa, melatih kemandirian siswa dan dapat belajar dimana saja dan kapan saja serta memformulasikan proses pengembangan media pembelajaran interaktif berbasis android untuk pembelajaran Teknik Animasi 2 dan 3 Dimensi yang valid, praktis dan efektif. Penelitian ini merupakan model pengembangan yang digunakan adalah ADDIE yang meliputi Analyze, Design, Development, Implementation dan Evaluation. Sumber data penelitian ini adalah siswa kelas XI Multimedia B SMK Negeri 4 Kota Padang berupa angket validitas, praktikalitas dan lembar efektivitas. Hasil penelitian didapatkan dari uji validitas 3 aspek yaitu hasil penilaian kelayakan oleh ahli materi dengan skor 0,776 kategori "Tinggi", penilaian ahli media dengan skor 0,844 kategori "Sangat Tinggi", penilaian ahli bahasa dengan skor 0,893 kategori "Sangat Tinggi". Praktikalitas siswa dengan skor rata-rata sebesar $87,97 \%$. Hasil Uji efektivitas hasil belajar siswa dari data pretest dan posttest diperoleh perhitungan t-tes thitung >ttabel, yaitu 17,66 $>1,71$ pada taraf signifikan $\alpha 0,05$. Berdasarkan data di atas dapat disimpulkan bahwa media pembelajaran interaktif berbasis android untuk pembelajan Teknik Animasi 2 dan 3 Dimensi valid, praktis dan efektif untuk digunakan dalam proses pembelajaran.
\end{abstract}

Kata Kunci: media pembelajaran, interaktif, android, pembelajaran teknik animasi 2 dan 3 dimensi

\begin{abstract}
The problems encountered in Instructional Animation Techniques 2 and 3 Dimensions namely some KD more directed at the level of understanding of the concept so that students need cognitive understanding. In the learning process many students are constrained in understanding the material from the teacher's explanation through video shows or power point slides so the teacher has to repeat the material that was previously delivered resulting in less effective learning. The tendency of students to prefer practical learning rather than theory so that cognitive learning outcomes are still low. This study aims to overcome these problems by developing android-based interactive learning media for Instructional Animation Techniques 2 and 2 Dimensions so that it can improve student learning outcomes, train student independence and be able to learn anywhere and anytime and formulate the process of developing androidbased interactive learning media for Instructional Animation Techniques 2 and 3 dimensions are valid, practical and effective. This research is a development model used is ADDIE which includes Analyze, Design, Development, Implementation and Evaluation. The source of the data of this study were students of class XI Multimedia B Vocational High School Of 4 Padang City in the form of a questionnaire of validity, practicality and effectiveness sheets. The results obtained from the 3 aspects of the validity test are the results of the appraisal assessment by material experts with a score of 0.776 in the category of "High", assessment of media experts with a score of 0.844 in the category of "Very High", the assessment of linguists with a score
\end{abstract}


of 0.893 in the category of "Very High". Practicality of students with an average score of $87.97 \%$. Test Results The effectiveness of student learning outcomes from the pretest and posttest data obtained by t-test tcalculation $>$ ttable is $17.66>1.71$ at a significant level $\alpha 0.05$. Based on the data above it can be concluded that the android-based interactive learning media for Instructional Animation Techniques 2 and 3 Dimensions is valid, practical and effective for use in the learning process.

Keywords: learning media, interactive, android, lnstructional animation techniques 2 and 3 dimensions

\section{PENDAHULUAN}

Pendidikan merupakan suatu proses untuk mempersiapkan generasi sekarang dan masa mendatang dengan mengembangkan potensi diri peserta didik, sehingga mampu menghadapi dan memecahkan problematika yang akan dihadapinya. Hal ini sesuai dengan Undang-undang Sistem Pendidikan Nasional Nomor 20 Tahun 2003 menyatakan pendidikan adalah usaha sadar dan terencana untuk mewujudkan suasana belajar dan proses pembelajaran agar peserta didik secara aktif mengembangkan potensi dirinya. Proses pendidikan dapat berlangsung sesuai dengan tujuan pendidikan nasional yaitu untuk mengembangkan manusia Indonesia dan mencerdaskan kehidupan bangsa. Manusia yang takwa dan iman kepada Tuhan Yang Maha Esa dan mempunyai budi pekerti yang luhur, mandiri, kepribadian yang mantap, kesehatan rohani dan jasmani, keterampilan dan pengetahuan dan mempunyai rasa tanggungjawab untuk berbangsa dan bermasyarakat.

Untuk menghasilkan peserta didik yang memiliki keterampilan dan pengetahuan, serta memiliki budi pekerti yang luhur, mandiri dan kepribadian yang mantap yang tertanam dalam diri peserta didik, perlu adanya Standar Kompetensi Lulusan. Hal ini tertuang dalam Peraturan Pemerintah No. 19 Tahun 2005 tentang Standar Nasional Pendidikan Bab I Pasal 1 yang menyatakan bahwa Standar Kompetensi Lulusan adalah standar kualifikasi kemampuan lulusan yang mencakup sikap, pengetahuan dan keterampilan. Untuk mencapai kompetensi lulusan tersebut perlu ditetapkan standar isi yang merupakan kriteria mengenai ruang lingkup materi dan tingkat kompetensi peserta didik untuk mencapai kompetensi lulusan pada jenjang dan jenis pendidikan tertentu. Hal ini sesuai dengan Permendikbud No. 21 Tahun 2016 tentang Standar Isi Pendidikan Dasar dan Menengah. Ketiga kompetensi tersebut memiliki proses pembelajaran yang berbedabeda, hal ini tidak lepas dari standar proses pembelajaran pada satuan pendidikan. Berdasarkan Permendikbud No. 22 Tahun 2016 tentang Standar Proses Pendidikan Dasar dan Menengah menjelaskan bahwa standar proses adalah kriteria mengenai pelaksanaan pembelajaran pada satuan pendidikan untuk mencapai standar kompetensi lulusan. Proses pembelajaran pada satuan pendidikan diselenggarakan secara interaktif, inspiratif, menyenangkan, menantang, memotivasi peserta didik untuk berpartisipasi aktif, serta memberikan ruang yang cukup bagi prakarsa, kreativitas dan kemandirian sesuai dengan bakat, minat dan perkembangan fisik serta psikologis peserta didik. Untuk itu setiap satuan pendidikan melakukan perencanaan pembelajaran, pelaksanaan proses pembelajaran serta penilaian proses pembelajaran untuk meningkatkan efisiensi dan efektivitas ketercapaian kompetensi lulusan. Oleh sebab itu untuk menghasilkan lulusan yang kompeten pada bidangnya serta memiliki etos kerja yang baik dalam kehidupan bermasyarakat, Pemerintah sebagai pengelola pendidikan perlu melakukan kegiatan-kegiatan pelaksanaan komponen sistem pendidikan yang sesuai dengan Standar Pendidikan Nasional melalui satuan pendidikan selaku penyelenggara pendidikan dalam menghadapi Era Industri 4.0 yang membutuhkan tenaga kerja yang memiliki keterampilan dalam literasi digital, literasi teknologi, dan literasi manusia (Yahya, 2018).

Gerakan literasi kebaruan memberikan dampak kepada dunia pendidikan abad 21. Pembelajaran abad 21 adalah pembelajaran yang menghasilkan peserta didik yang berkualitas dan kompeten, menguasai multidimensi yang dibutuhkan pada abad 21 yaitu pembelajaran yang menggabungkan fokus perpaduan keterampilan khusus, pengetahuan konten, keahlian dengan sistem pendukung yang inovatif. Menurut Smaldino dkk (2014) dasar untuk pengetahuan dan keterampilan abad 21 adalah persiapan peserta didik untuk pembelajaran bermakna dan sengaja menggunakan teknologi dan media untuk kreatifitas dan inovasi, komunikasi, penelitian dan pemecahan masalah. Dalam meningkatkan pengetahuan dan keterampilan siswa yang kompeten 
dibidangnya diperlukan Guru / fasilitator / pendamping / pendidik yang professional. Guru professional adalah guru yang mampu mengelola kompetensi diri dengan baik serta mampu mengelola kelasnya sehingga terjadilah interaksi antara guru dengan siswa, siswa dengan siswa.

Guru Profesional merupakan guru yang memiliki kemampuan dalam menguasai materi pembelajaran secara luas dan mendalam yang memungkinkan terintegrasikannya konten pembelajaran dengan penggunaan teknologi informasi dan komunikasi (TIK) dan membimbing peserta didik memenuhi standar kompetensi yang ditetapkan standar nasional Pendidikan (Karwati dan Priansa dalam Suyati, 2019). Selain dibutuhkan guru professional, dalam proses pembelajaran tercipta suasana joyful learning (Singh dalam Hendriyani, 2019). Untuk memberikan suasana tersebut diperlukan teknologi dan media penyampaian pengajaran menciptakan suasana belajar yang menyenangkan dan bermakna (joyful and meaningful learning) dan pembelajaran pun menjadi efektif dan efisien. Namun pada kenyataan di lapangan, masih banyak guru yang menggunakan cara tradisional dalam mentransfer ilmu yang berhubungan dengan aspek kognitif dalam bentuk konsep-konsep konkrit kepada peserta didik yaitu dengan metode ceramah sehingga peserta didik kesulitan dalam memahami konsep materi pelajaran tersebut. Masih banyak guru yang belum memanfaatkan media pembelajaran dengan inovasi dan teknologi terkini terutama pada pada satuan pendidikan Sekolah Menengah Kejuruan (SMK). Hal ini terjadi pada mata pelajaran Teknik Animasi 2 dan 3 Dimensi kelas XI Multimedia SMK Negeri 4 Kota Padang pada aspek kognitif. Mata Pelajaran Teknik Animasi 2 dan 3 Dimensi merupakan mata pelajaran wajib kompetensi kejuruan yang mempersiapkan peserta didik menguasai pembelajaran Animasi 2 dan 3 Dimensi.

Berdasarkan hasil wawancara peneliti dengan guru mata pelajaran Teknik Animasi 2 dan 3 Dimensi menjelaskan bahwa siswa sulit memahami materi pada KD 3.1 tentang Prinsip-prinsip Dasar Animasi. Mata Pelajaran Teknik Animasi 2 dan 3 Dimensi menekankan pada aspek kognitif dan psikomotorik. Beberapa KD lebih diarahkan kepada tingkat pemahaman konsep sehingga diperlukan pemahaman kognitif siswa. Pada saat pembelajaran beberapa siswa terkendala dalam memahami materi dari penjelasan guru serta tayangan video ataupun slide power point yang pada akhirnya guru harus mengulang kembali langkah kerja yang sebelumnya sudah disampaikan mengakibatkan pembelajaran tidak efektif. Siswa lebih cenderung menyenangi pembelajaran praktik ketimbang teori sehingga hasil belajar kognitif masih rendah. Masih terdapat siswa yang belum mencapai nilai sesuai dengan Kriteria Ketuntasan Minimal (KKM) yang telah ditetapkan sekolah yaitu 75 .

Sarana prasarana pada Kompetensi Keahlian Multimedia berupa Laboratorium Multimedia dengan 34 Personal Computer (PC) aktif dilengkapi periferal penunjang PC yang terkoneksi internet serta memiliki Studio Mini untuk praktek pembelajaran Multimedia. Sarana Kompetensi Keahlian Multimedia SMK Negeri 4 Kota Padang sangat menunjang proses pembelajaran jika dikelola dengan baik, namun permasalahan yang terjadi adalah kurang optimalnya pemanfaatan slide serta video pembelajaran yang merupakan media pembelajaran untuk menunjang proses pembelajaran. Slide presentasi yang disajikan oleh guru berupa gambar yang dilengkapi dengan video namun belum interaktif sehingga terjadi komunikasi satu arah, siswa hanya menyimak, mengamati dan mendengar penyampaian materi pembelajaran pada saat proses pembelajaran yang berlangsung tatap muka. Masih adanya guru yang belum memanfaatkan media yang seharusnya digunakan pada materi-materi yang membutuhkan media pembelajaran.

Pemanfaatan media pembelajaran berbasis teknologi seperti Lembar Kerja Peserta Didik / bahan ajar / modul, pembelajaran interaktif atau media pembelajaran lainnya belum tampak digunakan secara optimal. Guru tidak memiliki waktu banyak untuk membuat media pembelajaran yang lebih menarik minat belajar siswa. Keterbatasan waktu pembelajaran sedangkan materi yang disampaikan banyak baik bersifat konseptual maupun keterampilan sehingga penyampaian materi pembelajaran kurang dipahami siswa. Oleh karena itu variasi pemanfaatan berbagai media dalam proses pembelajaran sangat diperlukan yaitu media pembelajaran interaktif yang dapat memenuhi standar proses pendidikan yang dselenggarakan secara interaktif, inspiratif, menyenangkan, menantang serta memotivasi peserta didik untuk berpartisipasi aktif sehingga tercapai tujuan pembelajaran yang diharapkan. Media pembelajaran interaktif bisa dipelajari di mana saja dan 
kapan saja (Gunawan, 2019). Selain itu media pembelajaran interaktif lebih praktis ketimbang bahan ajar/ modul/ LKPD yang mudah rusak karena masih berbahan kertas.

Melihat masalah yang terjadi pada mata pelajaran Mata Pelajaran Teknik Animasi 2 dan 3 Dimensi tersebut, penggunaan media pembelajaran interaktif dirasakan perlu dalam pembelajaran. Selain dapat digunakan pada saat proses pembelajaran, media pembelajaran interaktif dapat dipelajari oleh siswa di luar pembelajaran sehingga mampu memberikan pemahaman konkrit yang pada akhirnya akan meningkatkan hasil belajar siswa. Salah satu media pembelajaran interaktif yaitu berbasis android. Android merupakan aplikasi dalam bentuk mobile merupakan solusi yang dapat menjawab kekurangan dari sistem pembelajaran yang sudah ada. Aplikasi ini mempunyai beberapa kelebihan diantaranya sebagai sebuah media edutainment, suatu media yang menggabungkan unsur edukasi (education) dengan hiburan (enterainment) atau belajar sambil bermain, mudah untuk dibawa kemana-mana karena terinstal dalam telepon seluler smartphone sebagai alat komunikasi sehari-hari, mudah karena yang diperlukan untuk menjalankannya hanya sebuah telepon genggam (handphone), efisien dalam penggunaannya, karena tidak menghabiskan banyak waktu.

\section{METODE PENELITIAN}

Penelitian ini menggunakan metode penelitian dan pengembangan (Research and Development $/ R \& D$ ). Menurut Sugiyono (2017) menyatakan bahwa metode R\&D penelitian dan pengembangan atau dalam bahasa Inggrisnya Research and Development $/ R \& D$ adalah metode penelitian yang digunakan untuk menghasilkan produk tertentu dan menguji keefektifan penggunaan produk tersebut. Dalam penelitian ini, produk yang dikembangkan berupa aplikasi multimedia interaktif berbasis android dimana pengembangan aplikasi ini mengacu pada model pengembangan ADDIE. Model ini terdiri dari lima tahap, yaitu (A)nalysis, (D)esign, (D)evelopment, (I)mplementation, dan (E)valuation. Pemilihan model ADDIE dikarenakan model ini menggambarkan secara sistematis untuk pengembangan pembelajaran. Model ADDIE ini dapat digunakan untuk berbagai produk seperti model, strategi pembelajaran, model pembelajaran, media dan bahan ajar (Mulyatiningsih, 2011). Selain itu, model ADDIE merupakan model yang sesuai untuk penelitian pengembangan dikarenakan proses pengembangannya berurutan dan interaktif, dimana hasil evaluasi setiap tahap dapat membawa pengembangan pembelajaran ke tahap selanjutnya. Tahapan penelitian yang dilakukan mengacu pada model pengembangan ADDIE yang dikembangkan Analysis, Design, Develop, Implement,Evaluate (Tegeh, Jampel, \& Pudjawan, 2014).

Tahap analisis (Analyze) untuk mengetahui kebutuhan yang akan digunakan dalam pengembangan media pembelajaran interaktif berbasis android melalui beberapa tahapan yaitu analisis kebutuhan, pemilihan kurikulum dan materi yang sesuai dengan kurikulum 2013 revisi 2017 semester ganjil. Tahap selanjutnya adalah tahap perancangan (design) dengan beberapa tahapan yaitu mengumpulkan sumber belajar yang sesuai dengan materi, memilah dan memilih materi yang relevan dan akurat sesuai dengan silabus mata pelajaran Teknik Animasi 2 dan 3 Dimensi, membuat peta konsep serta merancang flowchart dan storyboard serta menyiapkan bahan-bahan untuk penelitian dan pengembangan media. Tahap pengembangan media pembelajaran interaktif berbasis android terdiri dari beberapa tahapan antara lain mendeskripsikan komponen produk dan penggunaan yang terdiri dari 1) Petunjuk Penggunaan, 2) KIKD, 3) Materi Pembelajaran per KD, 4) Soal latihan, 5) Referensi yang berisikan daftar pustaka, modul pembelajaran, evaluasi berbasis online, video tutorial dan 6) Profil Peneliti. Selanjutnya merancang prototype dikembangkan dengan program Adobe Flash CS6 dan dibantu oleh program lainnya seperti Adobe Photoshop CS6, Adobe Premiere CS6, Form Google Doc. Pada tahap ini dilakukan validasi ahli. Validasi ahli terdiri dari 3 ahli yaitu ahli materi, ahli media dan ahli Bahasa.

Tahap implementasi merupakan tahap ujicoba penggunaan media yang dikembangkan terdiri dari uji praktikalitas untuk kpraktisan penggunaan media. Tahap evaluasi merupakan tahap akhir penelitian adalah evaluasi sumatif yaitu uji efektivitas aktivitas siswa dan hasil belajar siswa dengan melaksanakan pretest dilakukan pada awal penelitian untuk melihat kemampuan awal siswa sebelum menggunakan media pembelajaran interaktif yang dikembangkan dan posttest untuk melihat efektivitas hasil belajar siswa sesuai dengan KKM. Uji efektivitas aktivitas siswa melalui 
pengamatan terhadap siswa pada proses pembelajaran menggunakan media pembelajaran interaktif berbasis android yang dikembangkan sedangkan uji efektivitas hasil belajar melalui uji Normalitas untuk melihat normalitas data sebelum dilakukan uji Paired Sample T-test. Analisis Paired Sample T-test merupakan uji t yang dilakukan menggunakan aplikasi SPSS terhadap data pretest dan posttest. Teknik Analisis data efektivitas dilakukan dengan menghitung rerata skor untuk mengetahui peningkatan hasil belajar siswa.

\section{HASIL DAN PEMBAHASAN}

Pada penelitian ini telah dikembangkan produk pengembangan berupa Media Pembelajaran Interaktif Berbasis Android Untuk Pembelajaran Teknik Animasi 2 dan 3 Dimensi Kelas XI Sekolah Menengah Kejuruan. Dalam penelitian ini menggunakan model pengembangan ADDIE setiap tahapnya diikuti dan menghasilkan produk Media Pembelajaran Interaktif Berbasis Android yang layak, praktis dan efektif.

\section{Hasil Uji Validitas}

Prototype media pembelajaran interaktif berbasis android sebelum diujikan kepada subjek penelitian harus divalidasi terlebih dahulu oleh para ahli. Tujuannya untuk mengetahui kelayakan desain awal (prototype) media pembelajaran interaktif berbasis android tersebut. Validasi dilakukan oleh dosen ahli materi Jurusan Desain Komunikasi Visual FBS UNP, dosen ahli media Jurusan Teknologi Pendidikan FKIP UNP, Dosen ahli Bahasa dari Jurusan Bahasa FBS UNP. Dari uraian hasil validasi pada ahli dan uji pengembangan media pembelajaran interaktif berbasis android dapat disimpulkan pada tabel 1.

Tabel 1. Rekapitulasi Penilaian Validitas

\begin{tabular}{|l|l|l|l|}
\hline No. & Aspek Penilaian & Nilai Validitas & Kategori \\
\hline 1. & Materi & 0,776 & Layak \\
\hline 2. & Media & 0,844 & Sangat Layak \\
\hline 3. & Bahasa & 0,893 & Sangat Layak \\
\hline
\end{tabular}

Merujuk pada kategori kelayakan, maka hasil validasi pengembangan media pembelajaran interaktif berbasis android termasuk dalam kategori sangat layak. Setelah media pembelajaran interaktif berbasis android dinyatakan layak, dan melakukan perbaikan atas beberapa saran dan komentar dari pada ahli untuk mendapatkan produk yang baik sesuai dengan tujuan penelitian.

Adapun perbaikan (revisi) atas saran dan komentar yang disampaikan oleh para ahli terhadap media yang dikembangkan sebagai berikut:

1. Revisi Ahli Materi

Ditinjau dari aspek materi, terdapat beberapa bagian dalam media pembelajaran interaktif berbasis android yang perlu diperbaiki, yaitu:

a. Durasi teks pada video terlalu pendek sehingga tidak dapat dibaca jelas serta backsound yang terdengar terlalu kuat, sehingga perlu dilakukan perbaikan atau mengedit kembali video tutorial untuk menghasilkan video yang lebih baik lagi baik itu untuk tampilan teks maupun backsoundnya.

b. Gunakan prinsip You Eye You Exit (UI.UX), maksudnya perhatikan tampilan media terutama pada navigasi / link media pembelajaran yang dikembangkan sehingga menghasilkan media yang menarik dan mudah diingat oleh pengguna (user)

c. Untuk materi sebaiknya dilengkapi video tutorial, sehingga pengguna yang memiliki karakteristik auditori dan visual mampu memahami materi pembelajaran yang disajikan pada media pembelajaran yang dikembangkan ini.

2. Revisi Ahli Media

Ditinjau dari aspek media, terdapat beberapa bagian dalam media pembelajaran interaktif berbasis android yang perlu diperbaiki, yaitu:

a. Tidak menggunakan warna merah atau hijau pada teks. 
b. Kurangi penggunaan scrollbar pada aplikasi, gunakan pergantian slide jika materi pembelajaran yang disajikan terlalu banyak.

c. Tambahkan penomoran pada tombol navigasi.

3. Revisi Ahli Bahasa

Ditinjau dari aspek bahasa, terdapat beberapa bagian dalam media pembelajaran interaktif berbasis android yang perlu diperbaiki, yaitu:

a. Dari segi ketepatan, Bahasa aplikasi ini sudah bagus

b. Barangkali yang perlu diperbaiki adalah susunan format paragraph dan kerapian paragraf.

\section{Hasil Uji Praktikalitas}

Penilaian praktikalitas dilakukan terhadap 27 orang siswa kelas XI Multimedia B yang mengikuti pembelajaran Teknik Animasi 2 dan 3 Dimensi di SMK Negeri 4 Kota Padang. Berdasarkan hasil uji praktikalitas siswa, maka didapatkan rerata praktikalitas media pembelajaran interaktif berbasis android pada siswa sebesar 87,97\% dengan kategori sangat praktis. Merujuk pada kategori kepraktisan, maka nilai praktikalitas siswa termasuk dalam kategori sangat praktis. Maka dapat disimpulkan bahwa penggunaan media pembelajaran interaktif berbasis android media ini dikatakan sangat praktis digunakan dalam proses pembelajaran setiap harinya, sehingga pembelajaran Teknik Animasi 2dan 3 Dimensi lebih interaktif dan menyenangkan serta mampu meningkatkan hasil belajar siswa.

\section{Hasil Uji Efektivitas \\ Uji Efektivitas Aktivitas Belajar}

Tabel 2. Rekapitulasi Hasil Aktivitas siswa

\begin{tabular}{|l|l|l|l|}
\hline No. & Uraian Aktivitas & Nilai Persentase (\%) & Kategori \\
\hline 1 & Visual & 90 & Sangat Efektif \\
\hline 2 & Mendengar & 86,67 & Sangat Efektif \\
\hline 3 & Emosional & 86,67 & Sangat Efektif \\
\hline & Rata-rata & 87,78 & Sangat Efektif \\
\hline
\end{tabular}

Berdasarkan tabel 2 maka rata-rata nilai dari rekapitulasi hasil aktivitas siswa sebesar $87,78 \%$ dengan kategori sangat efektif, maka dapat disimpulkan bahwa media pembelajaran interaktif berbasis android sangat efektif digunakan dalam proses pembelajaran.

\section{Uji Efektivitas Hasil Belajar Siswa}

Uji efektivitas hasil belajar siswa diperoleh melalui kemampuan awal siswa sebelum diberikan perlakukan dengan menggunakan produk media pembelajaran interaktif berbasis android yang dikembangkan dan hasil belajar siswa setelah mendapatkan perlakukan. Uji Efektivitas hasil belajar siswa menggunakan One Group Pretest-Posttest Design dilakukan dengan memberikan pretest dan posttest kepada 27 orang siswa. Data uji efektivitas diuji dengan menggunakan aplikasi SPSS dengan uji normalitas dan Paired Sample T-test. Hasil uji normalitas dengan taraf nyata $\alpha 0,05$ untuk sampel 27 dapat dilihat pada tabel 3 sebagai berikut:

Tabel 3. Hasil Uji Normalitas Dengan Liliefors

\begin{tabular}{|c|c|c|c|c|c|c|}
\hline & Statistic & df & Sig. & Statistic & $\mathrm{df}$ & Sig. \\
\hline Pretest & .141 & 27 & .177 & .940 & 27 & .119 \\
\hline Posttest & .156 & 27 & .088 & .893 & 27 & .009 \\
\hline
\end{tabular}


Dapat diinterpretasikan bahwa melihat nilai statistik. pada kolom Kolmogorov-Smirnov ${ }^{\mathrm{a}}$.

Tabel 4. Rekapitulasi Hasil Uji Normalitas

\begin{tabular}{|c|c|c|c|}
\hline Tes & $\mathbf{L}_{\text {hitung }}$ & $\mathbf{L}_{\text {tabel }}$ & Keterangan \\
\hline Pretest & 0,141 & 0,173 & Normal \\
\hline Posttest & 0,156 & 0,173 & Normal \\
\hline
\end{tabular}

Berdasarkan Tabel 4 rekapitulasi hasil uji normalitas terlihat bahwa pretest $\mathrm{L}_{\text {hitung }} 0,141$ lebih kecil dari $\mathrm{L}_{\text {tabel }} 0,173$ untuk $\alpha 0,05$, maka nilai pretest berasal dari data yang berdistribusi normal. Untuk posttest diperoleh $\mathrm{L}_{\text {hitung }} 0,156$ lebih kecil dari $\mathrm{L}_{\text {tabel }} 0,173$ untuk $\alpha 0,05$. Dengan demkian nilai posttest berasal dari data yang berdistribusi normal. Setelah uji normalitas dilakukan, maka dilakukan dengan pengujian pairing t-test yaitu untuk mengetahui apakah terdapat perbedaan yang signifikan untuk nilai dari kedua kelompok.

Uji T dilakukan terhadap dua sampel yang berpasangan (paired); Sampel berpasangan yaitu sebuah sampel dengan subyek yang sama, namun terdapat dua perlakuan yang berbeda, subyek akan mendapat perlakuan pertama yaitu hasil belajar sebelum menggunakan media pembelajaran interaktif berbasis android, setelah itu subyek mendapatkan perlakuan kedua yaitu hasil belajar setelah menggunakan media pembelajaran interaktif berbasis android pada pembelajaran Teknik Animasi 2 dan 3 Dimensi. Ringkasan statistik dari tabel 5 hasil uji paired samples statistics dari kedua sampel sebagai berikut:

Tabel 5. Hasil Uji Paired Samples Statistics

\begin{tabular}{|ll|l|l|l|l|}
\hline & & Mean & N & Std. Deviation & Std. Error Mean \\
\hline Pair 1 & Posttest & 83.70 & 27 & 6.88 & 1.32 \\
& Pretest & 64.44 & 27 & 10.77 & 2.07 \\
\hline
\end{tabular}

Nilai capaian hasil belajar sebelum menggunakan media pembelajaran interaktif berbasis android peserta didik adalah 64,44, sedangkan nilai capaian hasil belajar setelah menggunakan media pembelajaran interaktif berbasis android peserta didik adalah 83,70. Hal ini dapat dinyatakan bahwa terdapat perbedaan Mean sebesar 19,26 (lihat nilai output SPSS). Angka ini berasal dari hasil belajar setelah menggunakan media pembelajaran interaktif berbasis android dikurangi hasil belajar sebelum menggunakan media pembelajaran interaktif berbasis android yaitu $83,70-64,44=19,26$. Selisih ini menunjukkan adanya peningkatan sebesar 19,26 dari rata-rata sebelum menggunakan media pembelajaran interaktif berbasis android. Berikut tabel hasil uji paired Samples test:

Tabel 6. Hasil Uji Paired Samples Test

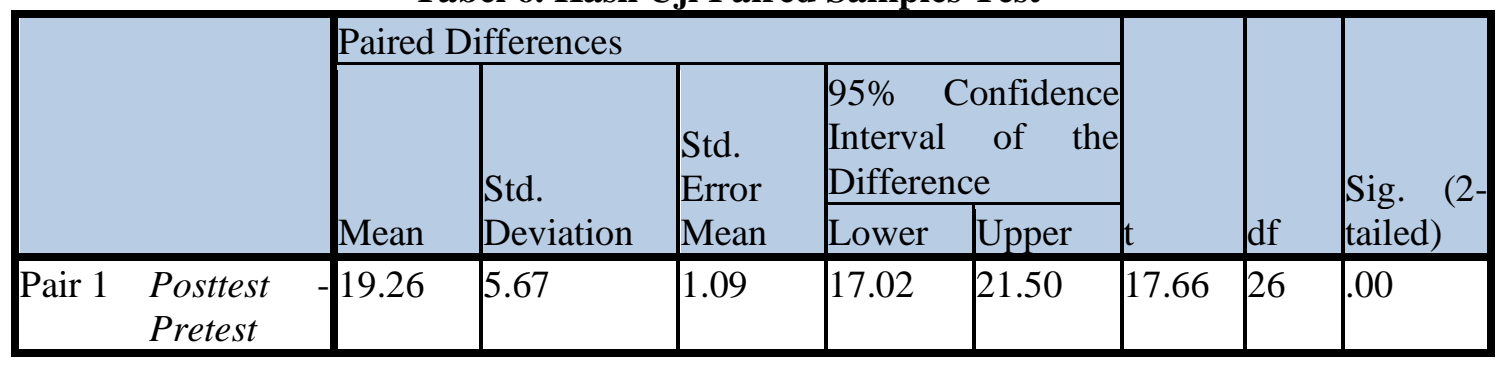

Pada tabel 6 hasil uji SPSS, maka dapat dilihat dari distribusi data yang ada pada kolom $\mathrm{t}$ berdasarkan perbandingan $t$ hitung dengan $t$ tabel maka dapat dijabarkan sebagai berikut:

1. Jika Statistik Hitung (t output) $>$ Statistik Tabel (tabel t) maka Ho ditolak.

2. Jika Statistik Hitung (t output) < Statistik Tabel (tabel t) maka Ho diterima.

Berdasarkan hasil analisis SPSS Uji T, T hitung dari output adalah 17,66. Untuk Statistik tabel bisa dicari pada tabel t, dengan cara: 
1. Tingkat signifikansi $(\alpha)$ adalah $10 \%$ untuk uji dua sisi sehingga masing-masing sisi menjadi $5 \%$

2. df (degree of freedom) atau derajat kebebasan dapat dicari dengan rumus jumlah data -1 yaitu 27-1 = 26, maka dapat diperoleh $\mathrm{t}$ tabel adalah 1,71.

Sehingga diperoleh data $\mathrm{t}$ hitung yaitu $1,71<17,66$ maka Ho di tolak. Jadi dapat disimpulkan bahwa media pembelajaran interaktif berbasis android pada pembelajaran Teknik Animasi 2 dan 3 Dimensi Kelas XI Sekolah Menengah Kejuruan signifikan yaitu rata-rata nilai Teknik Animasi 2 dan 3 Dimensi sebelum dan sesudah menggunakan media pembelajaran interaktif berbasis android terjadi perbedaan yang signifikan sehingga mengalami peningkatan. Selain melalui $t$ hitung dapat dilihat dari taraf signifikansi dilihat pada tabel adalah $0,00 \leq 0,05$ maka dapat dinyatakan terdapat perbedaan hasil belajar yang signifikan. Sehingga dapat disimpulkan bahwa penggunaan media pembelajaran interaktif berbasis android efektif dalam meningkatkan hasil belajar siswa kelas XI Multimedia B SMK Negeri 4 Kota Padang pada pembelajaran Teknik Animasi 2 dan 3 Dimensi. Berdasarkan pengujian data melalui uji T secara berpasangan dengan taraf uji mencapai 95\% dapat disimpulkan bahwa penggunaan media pembelajaran interaktif berbasis android pada pembelajaran Teknik Animasi 2 dan 3 Dimensi pda kategori sangat layak digunakan dalam proses pembelajaran. Media pembelajaran ini dapat menjadi solusi bagi pembelajaran Teknik Animasi 2 dan 3 Dimensi dengan memaksimalkan media pembelajaran yang ada di sekolah baik melalui komputer maupun smartphone.

\section{Pembahasan}

\section{Proses Pengembangan Media Pembelajaran Berbasis Android}

Tahap pertama pada pengembangan media adalah analisis (Analyze). Proses yang dilakukan adalah menganalisis kebutuhan, kurikulum dan materi. Media pembelajaran interaktif berbasis android ini ditujukan untuk siswa kelas XI Multimedia di SMK Negeri 4 Kota Padang. Konsep materi dari segi isi mengacu pada kurikulum 2013 revisi 2017 sedangkan konsep materi sesuai dengan peta konsep yang telah dirancang. Isi materi dari segi penyajian meliputi penjelasan materi yang berupa teks dan gambar, untuk proses pembuatan animasi disajikan dalam bentuk video tutorial. Konsep isi media secara keseluruhan terdiri dari petunjuk penggunaan, kompetensi dasar, materi pembelajaran (berisi tujuan pembelajaran dan uraian materi), soal latihan, referensi (berisi daftar pustaka, unduh modul, evaluasi online dan video tutorial) serta profil. Tahap kedua adalah perancangan (design), proses yang dilakukan pada tahap desain adalah perancangan materi, pembuatan flowchart dan storyboard, menyiapkan bahan-bahan/ sumber yang diperlukan dalam perancangan, menyusun instrumen.

Tahap ketiga adalah pengembangan (development), pada tahapan ini dilakukan pembuatan media pembelajaran interaktif berbasis android menggunakan Adobe Flash CS6. Pembuatan produk berdasarkan desain materi, flowchart dan storyboard yang telah dirancang. Pembuatan media pembelajaran interaktif berbasis android dilakukan dengan menggabungkan teks, gambar, audio, animasi dan video dalam scene-scene pada area kerja Adobe Flash CS6. Setelah produk yang dikembangkan, selanjutnya adalah validasi media pembelajaran interaktif berbasis android yang dilakukan oleh para ahli yang merupakan dosen Universitas Negeri Padang (ahli materi, ahli media dan ahli Bahasa) yang sebelumnya dilakukan validasi instrument terlebih dahulu oleh ahli instrumen sebelum dilakukan penilaian oleh para ahli validasi instrumen, Saran dan komentar dijadikan dasar untuk perbaikan media pembelajaran interaktif berbasis android yang dikembangkan. Setelah dilakukan perbaikan dan media dinyatakan layak oleh para ahli selanjutnya

Tahap keempat adalah implementasi (implementation), pada tahapan ini pengujian media pembelajaran yang digunakan dengan melakukan uji praktikalitas dilakukan oleh siswa kelas XI Multimedia B SMK Negeri 4 Kota Padang, namun sebelum uji praktikalitas, dilakukan pretest untuk melihat kemampuan awal peserta didik. Hasil pengujian ini digunakan untuk mengukur kepraktisan penggunaan media pembelajaran interaktif berbasis android dalam pembelajaran. Setelah uji praktikalitas dilakukan revisi produk jika dianggap perlu. Tahap terakhir adalah evaluasi (evaluation), tahap ini telah dilakukan pada setiap tahap model pengembangan dan setelah uji praktikalitas, proses terakhir pada tahap ini yaitu uji efektivitas aktivitas siswa dan efektivitas hasil 
belajar siswa dengan melakukan posttest untuk melihat hasil belajar siswa setelah memanfaatkan media pembelajaran interaktif berbasis android dalam pembelajaran. Efektivitas dinyatakan tinggi terlihat dari hasil belajar siswa setelah diberikan perlakuan sehingga tidak dilakukan revisi produk sebagai tahap evaluasi akhir. Setelah dilakukan penyimpanan dalam USB Flashdisk, media pembelajaran interaktif ini didistribusikan ke guru pengampu mata pelajaran Teknik Animasi 2 dan 3 Dimensi untuk dijadikan sebagai alat bantu mengajar dalam proses pembelajaran.

\section{Validitas, Praktikalitas dan Efektivitas Media Pembelajaran Interaktif Berbasis Android Untuk Pembelajaran Teknik Animasi 2 dan 3 Dimensi}

Hasil penelitian menunjukkan nilai validitas aspek materi termasuk pada kriteria tinggi yaitu 0,776 sehingga layak digunakan karena telah sesuai dengan Kurikulum 2013 Revisi 2017 dan Silabus. Validasi aspek media menunjukkan kriteria penilaian sangat tinggi yaitu 0,844 sehingga sangat layak digunakan karena media yang dikembangkan sudah sesuai dengan prinsip media pembelajaran interaktif dan seluruh menu yang terdapat pada media berjalan dengan baik. Validasi aspek bahasa menunjukkan kriteria penilaian sangat tinggi yaitu 0,892 sehingga sangat layak karena penggunaan bahasa sudah sesuai dengan kaidah bahasa Indonesia yang benar dan sesuai dengan Pedoman Umum Ejaan Bahasa Indonesia (PUEBI). Bahasa yang digunakan jelas, mudah dipahami oleh siswa dan komunikatif. Berdasarkan validitas dalam pengembangan media pembelajaran interaktif berbasis android untuk pembelajaran Teknik Animasi 2 dan 3 Dimensi, maka media pembelajaran interaktif berbasis android ini termasuk pada kategori sangat layak dan dapat diujicobakan serta dapat digunakan dalam proses pembelajaran. Uji praktikalitas dalam penggunaan media pembelajaran interaktif berbasis android dilakukan dengan melibatkan 27 siswa dilakukan dengan memberikan angket pada siswa. Berdasarkan penilaian praktikalitas oleh siswa diperoleh skor rata-rata sebesar $87,97 \%$. Penelitian ini juga didukung oleh data empiris yang menunjukkan bahwa penggunaan media pembelajaran interaktif berbasis android ini dalam kategori sangat praktis.

Berdasarkan data hasil uji efektivitas untuk aktivitas siswa rata-rata nilai dari rekapitulasi hasil aktivitas siswa sebesar $87,78 \%$ dengan kategori sangat efektif, maka dapat disimpulkan bahwa media pembelajaran interaktif berbasis android sangat efektif digunakan dalam proses pembelajaran. Hasil belajar siswa diperoleh dari lembar soal kemampuan awal siswa dan akhir kegiatan penelitian terhadap 27 siswa yang mengikuti pembelajaran Teknik Animasi 2 dan 3 Dimensi di Kelas XI Multimedia B. Pada lembar soal kemampuan siswa digunakan 20 butir soal dengan lima pilihan alternatif jawaban. Hasil nilai Pretest dan Posttest dengan nilai pretest adalah 64,44 dan posttest adalah 83,70 sehingga dapat disimpulkan bahwa terdapat peningkatan hasil belajar siswa. Hasil analisis data menggunakan pengujian pairing t-test, sebelum dilakukan pengujian hipotesis menggunakan pairing t-test, terlebih dahulu dilakukan uji normalitas dengan hasil kedua data berdistribusi normal. Analisis data menggunakan rumus pairing t-test didapat harga $t_{\text {hitung }}>t_{\text {tabel }}$, yaitu 17,66 $>1,71$ sehingga hasil belajar siswa yang mengikuti pembelajaran dengan media pembelajaran interaktif berbasis android untuk pembelajaran Teknik Animasi 2 dan 3 Dimensi lebih tinggi dibandingkan dengan hasil belajar siswa sebelum menggunakan media pembelajaran interaktif berbasis android untuk pembelajaran Teknik Animasi 2 dan 3 Dimensi. Penggunaan media pembelajaran interaktif berbasis android untk pembelajaran Teknik Animasi 2 dan 3 Dimensi efektif digunakan dalam meningkatkan hasil belajar siswa.

Hasil penelitian pengembangan media pembelajaran interaktif berbasis android, menunjukkan bahwa media pembelajaran interaktif berbasis android untuk pembelajaran Teknik Animasi 2 dan 3 Dimensi memberikan dampak positif dalam pembelajaran Teknik Animasi 2 dan 3 Dimensi. Dampak positif tersebut adalah dapat memudahkan siswa dalam pembelajaran. Siswa yang belum memahami materi pembelajaran pada proses pembelajaran di kelas, dapat mempelajari materi pembelajaran dimana saja dan kapan saja melalui smartphone berbasis android ataupun menggunakan komputer yang bantuan aplikasi Flash Player serta sesuai dengan kehidupan seharihari siswa. Selain itu juga mampu meningkatkan prestasi kognitif siswa serta motivasi siswa. Menurut Arsyad (2014), bahwa media pembelajaran akan lebih menarik perhatian siswa sehingga dapat menumbuhkan motivasi belajar. 
Forum diskusi disediakan bagi siswa untuk saling berbagi dan bertukar pikiran mengenai permasalahan atau materi pembelajaran Teknik Animasi 2 dan 3 Dimensi yang telah dibahas atau pun belum dibahas pada pertemuan tatap muka di kelas serta dapat berkomunikasi langsung dengan guru melalui forum diskusi tersebut yang berkaitan dengan pembelajaran. Kemudahan penggunaan media pembelajaran interaktif berbasis android untuk pembelajaran Teknik animasi 2 dan 3 Dimensi juga dirasakan oleh guru pengampu mata pelajaran yang memiliki mobilitas tinggi dalam menjalankan tugasnya sebagai kaprodi kompetensi keahlian Multimedia. Guru dapat memberikan evaluasi secara online pada siswa. Penyampaian materi pembelajaran dalam bentuk modul dapat diunduh oleh siswa secara online tanpa harus melakukan proses pembelajaran dalam kelas sehingga siswa bisa mempelajari materi pembelajaran sebagai sumber belajar dan dapat mempelajari materi pembelajaran dimana saja dan kapan saja. Kelebihan media pembelajaran interaktif berbasis android dapat digunakan di mana saja dan kapan saja tanpa terikat ruang dan waktu. Kelebihan ini didukung oleh perangkat android yang ukurannya kecil, ringan, dan mudah dibawa kemana saja (Lubis \& Ikhsan, 2015). Selain kelebihan produk yang telah disebutkan diatas, media pembelajaran interaktif berbasis android yang dikembangkan memiliki kelemahan. Adapun kelemahan media pembelajaran berbasis android yang dikembangkan tidak dapat dioperasikan pada smartphone dengan sistem operasi berbasis android. Hal tersebut dibenarkan dengan penelitian yang dilakukan oleh Rohmi Julia Purbasari (2017).

\section{Kesimpulan}

\section{KESIMPULAN, IMPLIKASI DAN SARAN}

Berdasarkan rumusan masalah, tujuan dan pembahasan mengenai media pembelajaran interaktif berbasis android untuk pembelajaran Teknik animasi 2 dan 3 dimensi disimpulkan bahwa: 1) Media pembelajaran interaktif berbasis android untuk pembelajaran Teknik Animasi 2 dan 3 Dimensi pada Kelas XI Sekolah Menengah Kejuruan telah berhasil dikembangkan dengan program Adobe Flash CS6 dan dibantu oleh program lainnya seperti Adobe Photoshop CS6, Adobe Premiere CS6, Form Google Doc agar tampilan media pembelajaran lebih menarik dan dapat dioperasikan pada smartphone siswa, 2) Uji Validitas media pembelajaran interaktif berbasis android berdasarkan hasil penilaian oleh ahli media, ahli materi dan ahli Bahasa memperoleh skor 0,776 ahli media masuk dalam kategori tinggi, 0,844 ahli media masuk dalam kategori sangat tinggi dan 0,893 ahli Bahasa masuk dalam kategori tinggi dan dilakukan perbaikan produk sebanyak satu kali sesuai dengan komentar dan saran validator dan lanjut pada tahap selanjutnya, 3) Hasil uji praktikalitas media pengembangan interaktif berbasis android untuk pembelajaran Teknik Animasi 2 dan 3 Dimensi memperoleh penilaian sebesar 87,97\% berdasarkan angket respon siswa kelas XI Multimedia B SMK Negeri 4 Kota Padang, 4) Hasil Uji efektivitas hasil belajar siswa dari data pretest dan posttest diperoleh perhitungan t-tes thitung $>$ ttabel, yaitu 17,66 $>1,71$ pada taraf signifikan $\alpha 0,05$.

\section{Implikasi}

Berdasarkan temuan hasil penelitian maka implikasi pada penelitian dan pengembangan ini adalah sebagai berikut: 1) Media pembelajaran interaktif berbasis android terbukti dapat mempengaruhi hasil belajar siswa pada pembelajaran Teknik Animasi 2 dan 3 Dimensi. Sebagaimana yang telah dikemukakan dalam pembahasan mengenai hipotesis penelitian, membuktikan adanya pengaruh positif yang signifikan antara media pembelajaran interaktif berbasis android untuk pembelajaran Teknik Animasi 2 dan 3 Dimensi terhadap hasil belajar siswa Kelas XI Multimedia B SMK Negeri 4 Kota Padang, 2) Hasil penelitian sebagaimana yang telah dibahas menunjukkan adanya hubungan antara teori dengan hasil penelitian. Dengan diterimanya hipotesis adanya pengaruh positif yang signifikan antara media pembelajaran interaktif berbasis android untuk pembelajaran Teknik Animasi 2 dan 3 Dimensi terhadap hasil belajar siswa menunjukkan adanya bahwa dalam meningkatkan hasil belajar siswa perlu dikembangkan media pembelajaran interaktif berbasis android. 


\section{Saran}

Berdasarkan hasil penelitian dan pengembangan ini, maka dapat disarankan hal-hal sebagai berikut: 1) Media pembelajaran interaktif berbasis android hasil pengembangan diharapkan dapat digunakan untuk pembelajaran Teknik Animasi 2 dan 3 Dimensi, sehingga akan mempermudah siswa dalam memahami materi yang disajikan, 2) Produk penelitian dan pengembangan dapat memberikan manfaat bagi pembelajaran, maka disarankan kepada guru untuk mengembangkan produk ini dengan cakupan yang lebih luas ataupun pada materi lain, bahkan pada mata pelajaran lain pada waktu yang mendatang, 3) Perlunya penambahan soal latihan yang lebih beragam sesuai dengan tingkat pemahaman siswa, 4) Perlu dilakukan pengembangan lebih lanjut terhadap media pembelajaran interaktif berbasis android untuk meningkatkan kualitas pembelajaran Teknik Animasi 2 dan 3 Dimensi Sekolah Menengah Kejuruan pada aspek psikomotorik.

\section{DAFTAR REFERENSI}

Arsyad, A. (2011). Media Pembelajaran. Jakarta: Raja Grafindo Persada.

Asmoro, S. W., \& Pramono, J. (2019). Animasi 2D\&3D Kompetensi Keahlian Multimedia Program Keahlian Teknik Komputer SMK/MAK Kelas XI. Yogyakarta: Penerbit Andi.

Gunawan, W. (2019). Pengembangan Aplikasi Berbasis Android Untuk Pengenalan Huruf Hijaiyah. Jurnal Informatika, 6(1), 69-76. https://doi.org/10.31311/ji.v6i1.5373

Hendriyani, S. dan R. (2019). Pengembangan Media Pembelajaran Game Animasi Interaktif Berbasis Android Untuk Meningkatkan Pemahaman Konsep Pada Materi Sistem Gerak Kelas XI. BioEdu: Berkala Ilmiah Pendidikan Biologi, 8(2), 185-193. Retrieved from https://jurnalmahasiswa.unesa.ac.id/index.php/bioedu/article/view/28829

Kebudayaan, K. P. (2017). Materi Pendukung Literasi Digital ; Gerakan Literasi Digital (Tidak Diterbitkan ed.). Jakarta: Kementrian Pendidikan dan Kebudayaan.

Kemendikbud. (2016). Permendikbud No. 20 Tahun 2016 Tentang Standar Kompetensi Lulusan Pendidikan Dasar dan Menengah. Jakarta: Kemendikbud.

Kemendikbud. (2016). Permendikbud No. 21 Tahun 2016 Tentang Standar Isi Pendidikan Dasar dan Menengah. Jakarta: Kemendikbud.

Kemendikbud. (2016). Permendikbud No. 22 Tahun 2016 Tentang Standar Proses Pendidikan Dasar dan Menengah. Jakarta: Kemendikbud.

Lubis, I. R., \& Ikhsan, J. (2015). Pengembangan Media Pembelajaran Kimia Berbasis Android Untuk Meningkatkan Motivasi Belajar Dan Prestasi Kognitif Peserta Didik SMA. Jurnal Inovasi Pendidikan IPA, 1(2), 191.

Mulyatiningsih, E. (2011). Riset Terapan Bidang Pendidikan dan Teknologi (1 ed.). Yogyakarta: UNY Press.

Purbasari RJ, M. K. \& M. Y. (2017). Pengembangan Aplikasi Android Sebagai Media Pembelajaran Matematika Pada Materi Peluang Untuk Siswa SMA Kelas X. Jurnal LEMMA, 4(1).

Smaldino, S., Lowther, D. L., \& Rusell, J. D. (2014). Instructional Technology and Media For Learning (Edisi Sepuluh ed.). New York: Macmillan Publishing Company.

Sugiyono. (2017). Metode Penelitian \& Pengembangan (Research and Development /R\&D) untuk Bidang Pendidikan, Manajemen, Sosial, Teknik. Bandung: Alfabeta.

Suyati. (2019). Meningkatkan Peranan Guru Profesional Dalam Menghadapi Era Revolusi Industri 4.0. Prosiding Seminar Nasional Pendidikan Program Pascasarjana Universitas Pgri Palembang, 957-963. Retrieved from https://jurnal.univpgripalembang.ac.id/index.php/Prosidingpps/article/view/2656

Tegeh, I. M., Jampel, I. N., \& Pudjawan, K. (2014). Model Penelitian Pengembangan (Edisi Pertama ed.). Yogyakarta: Graha Ilmu.

Undang-undang Negara Republik Indonesia. (2003). Undang-Undang No. 20 Tahun 2003 Tentang Sistem Pendidikan Nasional.

Yahya, M. (2018). Era Industri 4.0: Tantangan Dan Peluang Perkembangan Pendidikan Kejuruan Indonesia. Retrieved from http://eprints.unm.ac.id/6456/. 